\section{Persistent Mild Pyrexia}

Dr. Thos. McCulloch (Cambuslang) writes: I wonder if any reader can throw light on a question which is causing me a little anxiety-namely, Can the normal body temperature be higher than $98.6^{\circ} \mathrm{F}$.? What prompts this query is the fact that $I$ have under my care a little girl whose temperature has only on one or two occasions since July been lower than $98.6^{\circ} \mathrm{F}$. The condition causing the pyrexia at that time was a mild attack of tonsillitis accompanied by slight enlargement of the tonsillar gland on one side. This cleared up in a few days; but the child's mother took the temperature regularly for several weeks afterwards, and found it to be raised on every occasion. The average daily readings are $98.6^{\circ}$ in the morning and $98.8^{\circ}$ to $99^{\circ}$ in the evening. I have examined the child very carefully for lung conditions, . etc. but am quite unable to discover any cause. She is aged 7 , goes to school every day, and behaves and plays about like any healthy young animal. I shall be glad to know of anyone having met with a similar case.

Catarrh of Upper Respiratory Tract

Dr. B. M. SмYтн (Srinagar, Kashmir) writes: In the Journal of June 13th "S. S." inquires about catarrh of the upper respiratory tract. I myself have been a sufferer from this complaint for many years, when compelled to live under certain climatic conditions, such as the dust of the Punjab or the smoke and fogs of large English cities. I have tried every sort of palliative remedy, and have found relief on two occasions only. One was when I had protein shock (intravenous T.A.B.). On this occasion the catarrh stopped immediately and completely for some weeks, and then returned gradually. I should have repeated the treatment but for the fact that my reaction was so severe as to be dangerous. The other thing that has relioved it been exposure to radiant heat, and also the high-frequoney " "Fidio": current. On two occasions a severe attack has been completely stopped within two days with this treatment.

"G. P." lodged his declaration of income, computing his assessaste income for 1931-32 on the amount of his earnings for the year ended March 31st, 1981. Owing to ill-health he has recently had to employ an assistant for some months, and may have to continue doing so for some time. Can he claim any adjustment in view of the consequent drop in his net earnings?

$\because$ No ; unfortunately such circumstances do not justify a departure from the previous year's basis, though it could have been arranged otherwise if "G. P." had taken a partner instead of an assistant into the practice.

\section{Housekeeper Allowance}

"M. N." asks for further information with regard to this allowance.

** The deduction (of $£ 50$ ) is given to a widower or widow whether there are children to be cared for or not, and to unmarried persons who have a female relative acting as housekeeper where the person making the claim has the care of a brother or sister. Hence it does not apply to the quite common case of a bachelor employing a housekeeper for his own comfort and not directly or indirectly for the care of a brother or sister.

\section{LETTERS, NOTES, ETC.}

\section{The "Electrick" Piano Trick}

Dr. A. B. DunNe (Doncaster) writes: Some few weeks ago I received a ticket for a lottery organized by the Revista Internacional Medical, addressed to me from Calle Mayor, 49, Villanueva y Geltrú, and bearing the Barcelona postmark. I am, I fear, a very careless fellow, and threw it into the wastepaper basket, and thought no more about it. However, that was not the end of the matter, for this week I received the gratifying and (certainly on my part) wholly unexpected news from the firm that the ticket which I had so lightheartedly thrown away, without even making a note of its number, had drawn the second prize- " an electrick piano.". My joy at this windfall, however, was tempered' by the fact that I have already in my house a pianola, a wireless set, and my daughter's gramophone, and as my house is not connected with the electric company's main I have no use for this valuable instrument, which wil be shipped to London and forwarded free of cost to any address in England, etc. As I have no use for this instrument I shall be glad to let any hospital or other institution have it; but before they can become the fortunate pos- sessors, there is one little matter to be attended to. It appears that, under the conditions governing the lottery, subscribers to the journal can alone receive a prize. I, unfortunately, have hitherto not been a subscriber, and so, prior to shipping the "electrick" piano to London, they ask me to forward a remittance of $£ 210 \mathrm{~s}$. 3d. as soon as possible " in mandat or order de post or cheque, addressed to our director, Mr. Vicente Peris, Calle Mayor 49, Villanueva y Geltrú." Needless to say, I have not done so. This enterprise of the Revista Internacional Medical, I think, Mr. Editor, is well worth the consideration of your colleagues of the British medical press, and might be a further inducement to subscribe to their periodicals. Free insurance policies are poor stuff in comparison. Have any of your readers been lucky, along with me, in winning the "electrick" piano?

** Several other medical men in the North of England inform us that they also have won the "electrick" piano, and in each case the number of the ticket that won the prize was 7890 ! We are glad to know that none of them has parted with £2 $10 \mathrm{~s}$. 3d., and we hope that every prizewinner has been equally incredulous.

\section{The Post-Influenzal Cough}

Dr. K. R. Dalal (health officer, Corporation of Rangoon) writes: Every practising physician will have read with great interest the very useful contribution made to our knowledge of this distressing trouble by Dr. G. Richardson in the Journal of April 18th. These persistent paroxysms of irritating cough, mostly coming on when lying down in bed at night, and whenever exposed to cold air or draught following an attack of influenza, once started are very hard to control, and bear a close resemblance to its of whooping-cough. As stated by Dr. Richardson, most of us will agree that the treatment of this distressing sequel is most disappointing. However, I should like to bring to the notice of the medical profession one drug that I have found most useful in this condition in the few cases in which I have tried it. This is a synthetic drug called " acedicon," prepared by C. H. Boehringer Sohn of Hamburg in tablet form, containing 1/13 grain in each. For adults, half to one tablet may be given when required. I am indebted to Professor W. Griesbach of Hamburg University for bringing it to my knowledge during his tour of the Eastern countries last year.

\section{Urobilinogen}

Dr. Sheffield Neave (Huntly) writes: In reference to Dr. Chalmers's letter (October 24th, p. 780), I, too, have been making this test on various cases of illness, although. being on a holiday, I have not access to my notes for particulars. I may say there is a point which lessens the importance of this finding-namely, that it is common to find the reaction disappear as the patient gets well. This is notably so in common constipation, which often gives a positive reaction.

\section{Pseudo-Hermaphroditism}

Messrs. J. B. Neal and R. Cox (King's College, London) write: In the interesting memorandum by Mr. G. S. Woodman on pseudo-hermaphroditism (October 24th, p. 750), we observe that there is no definite reference to secondary sexual ${ }^{-}$characters, such as development of mammae, voice, and hair, although the patient is referred to as "she." The presence of female secondary characters seems improbable in the absence of ovaries, while the presence of a testis should predispose to masculine secondaries. * We feel that it would be interesting to have further information about the type of secondary characters.

\section{Toxaemias of Pregnancy Correction}

The report of Professor F. J.- Browne's address to the City Division on the toxaemias of pregnancy, published in last week's Supplement, contained an error which should be corrected without delay (page 235 , bottom of column 2). Professor Browne did not recommend hysterectomy as a method of terminating pregnancy, which would be unjustifiable in any circumstances. He did recommend abdominal hysterotomy.

\section{Vacañcies}

Notifications of offices vacant in universities, medical colleges, and of vacant resident and other appointments at hospitals, will be found at pages $42,43,44,45,48$, and 49 of our advertisement columns, and advertisements as-- to partnerships, assistantships, and locumtenencies at pages 46 and 47.

A short summary of vacant posts notified in the advertisement columns appears in the Supplement at page 259. 